\title{
A note on non-canonical passives: the case of the get-passive
}

\section{Artemis Alexiadou}

\section{Introduction ${ }^{1}$}

In many languages, a passive-like meaning may be obtained through a noncanonical passive construction. The get passive (1b) in English, the se faire passive (2b) in French and the kriegen passive (3b) in German represent typical manifestations: ${ }^{2}$

(1) a. John was killed in the war.

b. John got killed in an accident.

(Haegeman 1985:53)

(2) a. Jean etait écrasé par une voiture.

Jean was run-over by a car

b. Jean s'est fait écraser (par une voiture).

Jean refl aux made run-over (by a car)

'Jean was run over by a car.'

(Labelle 2002:1)

\footnotetext{
${ }^{1}$ I am really happy that I can offer this squib to Henk with gratitude for his support and guidance over the years. Thanks are due to David Embick, Winfried Lechner and Florian Schäfer for comments and discussion.

${ }^{2}$ For English, see Siewierska (1984), Haegeman (1985), Arce-Arenales et al. (1994), Givón and Yang (1994), Fox and Grodzinsky (1998), Huang (1999), Taranto (2004), and McIntyre (2005) among others and references therein; for French, see Labelle (2002) and references therein; for German, there is a lengthy dispute as to whether or not this is a passive structure, see Haider (1984), (1986), (2001), Fanselow (1987), Reis (1985), Cook (2004) among others.

In addition to kriegen, erhalten and bekommen 'receive/get' may be used as passive auxiliaries in German. As Siewierska (1984) and references therein notes, the three auxiliaries are not interchangeable. Note that in German the kriegen construction promotes only a dative argument which, for some speakers, must cooccur together with an accusative argument, as in (3c).
} 
(3) a. Hans wurde getötet.

Hans was killed

b. Er kriegte seine Miete von der Firma bezahlt. He got his rent by the firm paid

(Siewierska 1984:132)

This squib focuses on the behavior of the get-passive in English and discusses a number of restrictions associated with it as well as the status of get.

The get-construction and its cognates in the other languages are particularly interesting as they raise a number of questions for both the analysis of passives as well as for the standard distinction between major lexical heads and functional heads, and the potential existence of semilexical heads (see Riemsdijk 1998: 1-48, Haider 2001). Standardly, functional heads are assumed to lack a lexical-conceptual argument structure, they select their complement solely in terms of morphosyntactic and category features of the head of the complement. Van Riemsdijk (1998) provided convincing arguments for the existence of semi-lexical heads in the nominal domain, and a number of the contributions to Corver and Van Riemsdijk (2001) suggest the existence of these heads in the verbal domain.

With respect to this partition, this squib will suggest that get is a further instantiation of a semi-lexical head in the verbal domain. In particular get will be seen here as the semi-lexical variant of a major lexical head, since it lacks argument selection properties (Emonds 1999, Van Riemsdijk 1998, Haider 2001). This becomes clear if we contrast (1b) with the examples in (4) and (5). While in (1) get does not seem to license the thematic role of the subject, it permits constructions where it does seem to license argument structure. These include (a) cases in which it functions as a 'lexical' verb (4) and (b) constructions which are active/causative, where the subject is interpreted as the causer of the action described by the participial clause (5). The behavior shown by get is similar to that of have and need in English which have been discussed in the literature:

(4) Susan got a book. ${ }^{3}$

(5) John got Mary blamed for the accident.

\footnotetext{
${ }^{3}$ McIntyre (2005) discusses a further reading of get, which he labels 'hindrance' reading, illustrated in (i). (i) means that the result is hard to attain:
}

(i) I didn't get the key in the lock. 
The semi-lexical nature of get is manifested by a series of criteria that disambiguate pure functional heads, e.g. auxiliaries and lexical verbs. As demonstrated in examples of the type in (1b), get patterns more like a lexical verb than like an auxiliary, in that it shows an atypical behavior for auxiliaries in a number of contexts, including negation contraction and question formation (6):

(6) a. Did he get killed?/Was he killed/*Got he killed.

b. He didn't get killed/He wasn't killed/*He gotn't killed.

In what follows, I briefly summarize the properties of the get-passive as these have been described in the literature.

\section{The properties of the get-passive}

Leaving aside the issue of the appropriate register (spoken vs. written language), a certain consensus seems to exist as far as the properties of the get-passive is concerned. First of all, unlike their be counterparts, the get passives lack an implicit external argument, since they are unable to control into purpose clauses and cannot license volitional adverbials (Huang 1999, Fox and Grodzinsky 1998, Taranto 2004 and others):

(7) a. The ship was sunk [PRO to collect insurance money].

b. *The ship got sunk [PRO to collect insurance money].

c. The ship got sunk [for John to collect insurance money].

(8) a. The book was torn on purpose.

b. *The book got torn on purpose. (Fox and Grodzinsky 1998:327)

As discussed in Fox and Grodzinsky (1998), these contrasts all lead to the same conclusion: in get-passives, unlike in be passives, the external argument of the VP has no implicit realization.

Second, as pointed out by Arce-Arenales et al. (1994), get-passives are compatible with reflexive action, while be-passives are not:

(9) a. I got dressed (by my mother or by myself).

b. I was dressed (only by my mother).

This is reminiscent of Kratzer's discussion on German participles, where she shows that the following distinction holds: 
(10)a. Das Kind war gekämmt. The child was combed

Stative: compatible with reflexive action (no agent)

b. Das Kind wurde gekämmt.

The child was combed

Eventive: incompatible with reflexive action (necessarily an agent)

The above two properties seem to suggest that the participle involved is actually an adjectival passive. In fact, this is the conclusion drawn by both Fox and Grodzinsky and Taranto.

A further argument in favor of this view is provided by the thematic restrictions that have been observed for adjectival participles. As noted by Levin and Rappaport (1986) among others, adjectival passives of some (in fact the majority of) double object verbs do not allow goal externalization, while both arguments can be externalized in the case of the verbal passive:

(11)a. The salesman sold the customer a car.

b. The recently sold car

c. *The recently sold customer

(12) a. The car was sold to the customer.

b. The customer was sold a car.

If the get-passive is based on the adjectival participle, one might expect similar restrictions on what passives are possible there. (13) confirms this: goal externalization is not possible:

(13) a. The car got sold to the customer.

(Siewierska 1984: 132)

b. ??The customer got sold a car.

The third property characterizing the get-passive is that, as opposed to the $b e$-passive, it does not seem to be fully productive: ${ }^{4}$

\footnotetext{
${ }^{4}$ Note, however, that verbs that do not normally have transitive counterparts can form the get-passive (see Arce-Arenales 1994: 15):

(i) a. He got fogged in.

b. *The weather fogged him in.

c. The cotton balls got decayed.

d. *The bad weather decayed the cotton balls.
} 
(14) a. *The truth got known.

b. *Mary got feared.

c. *Mary got followed by a little lamb.

d. *Mary got seen.

e. *The electricity light got invented.

It has been noted that the get-passive is not permitted with stative verbs and verbs that do not allow for the subject of the construction to be interpreted as affected. Some researchers even classify the construction as an adversative passive. As Siewierska (1984: 161) notes, the get-passives describe events that are perceived to have a fortunate or unfortunate consequence on the subject. ${ }^{5}$

\section{Towards an explanation}

\subsection{What kind of adjectival participle?}

The discussion in the previous section suggests that in the get-passive the status of the participle is unlike its be-counterpart, namely it involves an adjectival participle. The question I turn to here is what type of adjectival participle is actually present in the structure, in view of recent work by Kratzer (2001), Embick (2003) and others. These authors pointed out that adjectival participles fall into several (at least two) sub-types depending on whether or not they carry event implications.

One potential clue for distinguishing between the two types of adjectival participles comes from their form. While in most cases, English participles are homophonous, Embick (op.cit.) noted that there are also instances in which a pure stative meaning, i.e. a meaning void of event

\footnotetext{
${ }^{5}$ This property brings the get-passive close to the restrictions that hold for middle formation as well as passive nominals in English.

(i) a. the city's destruction/*the book's knowledge

b. The wood slits easily/*the cat chases easily

One line of understanding the notion of affectedness suggests that this has to with properties of the event structure of the predicates. In particular, Doron and Rappaport-Hovav (1991) define Affectedness over event structure representations and claim that what characterizes it is the separation of the arguments of the verb into different sub-eventualities, with the external argument missing from one of the sub-eventualities. Destroy is such a predicate type, i.e. one can distinguish between two eventualities, know is not such a predicate type, as one cannot distinguish between sub-eventualities. Taranto's account builds on that.
} 
implications is mapped on a distinct phonological realization. As shown in (15), the designated form is reserved for the stative participle:

$\begin{array}{llll} & \text { Root } & \text { Stative } & \text { Other Participles } \\ \text { 1. } & \sqrt{\text { ROT }} & \text { rott-en } & \text { rott-ed } \\ & \sqrt{\text { SINK }} & \text { sunk-en } & \text { sunk } \\ \text { 2. } & \sqrt{\text { EMPTY }} & \text { empty } & \text { empti-ed } \\ & \sqrt{\text { DRY }} & \text { dry } & \text { dri-ed }\end{array}$

It is possible to combined both forms with get and the constructions differ in interpretation as follows:

(16) The mailbox got empty.

(17) The mailbox got emptied.

In (17) the subject of get is affected by the event described in the complement of get in the sense that someone is understood to have emptied the mailbox. This is not the interpretation associated with (16), where the reading is that the mailbox became empty. Taranto also observes that the get construction as a whole is eventive. Thus get selects both stative as well as eventive complements. The former are pure states, lack functional layers that bring about eventivity, the latter contain such a layer but lack a functional projection that introduces agentivity features, as shown in section 2 .

Another test that can be used to provide evidence for the participial structure in the complement of get concerns the distribution of adverbs. As the data in (18) show, the participle under get can be modified by adverbials which modify the result state, but not by adverbs that bring about agentivity/intentional interpretation (cf. McIntyre 2005): ${ }^{6}$

(18) a. John got sloppily dressed.

b. ??The manuscript got carefully destroyed.

The fact that only result oriented adverbs are fully grammatical within the get-constructions seems to suggest that the complement of get is a participle that carries eventivity features. The construction thus seems to

\footnotetext{
${ }^{6}$ Following Alexiadou and Anagnostopoulou (2005), I assume that there are two types of manner adverbials, namely manner adverbs that modify the visible result of an event such as 'sloppily'(result-oriented) and manner adverbs that modify the initiator of the action such as 'carefully' (agent-oriented).
} 
bear similarities to Kratzer's resultant state participles. In support of that note that it is incompatible with for-PPs (e.g. The table was $/{ }^{*}$ got wiped for an hour, noted by Fox and Grodzinsky 1998: 315).

However, there is an important difference between resultative participles and the get-construction: resultative participles do not license by-phrases, but get-passives do:

(19) a. *John is arrested by the police.

b. John got arrested by the police.

Data like the above suggest that the $b y$-phrase is not licensed directly by the resultative participle but its licensing happens in a different fashion. Fox and Grodzinsky (1998) suggested that the licensing of the $b y$-phrases in the get-passive follows the pattern of the licensing of by-phrases in nominalisations and is only restricted to the affector role. Arce-Arenales and al. (1994) label the by-phrases involved in the get-construction pseudoagentive phrases. Alternatively, one could assume that the important difference between (19a) and (19b), and hence the locus of licensing of the by-phrase, is the presence of get.

\subsection{The structure of the get-passive}

Here I will merely sketch the structure I assume for the get-passive. Richards (2001) and Harley (2004) propose that in the transitive use of get, as in Susan got a book, this is decomposed into a BECOME and HAVE layer. Incorporation of HAVE into BECOME yields get: ${ }^{7}$

\section{(20)}

\section{[vp BECOME [pP Susan [HAVE a book]]]}

At this stage, it is not clear how this structure can be used for passive get, as it does not seem to be able to explain the properties of the construction.

Building on Haegeman (1985), I assume that get is actually a light verb that receives a resultative phrase (RP), i.e. the resultative participle, as its complement. The participle resembles the structure assumed for resultative stative participles in e.g. Alexiadou and Anagnostopoulou (2005) and

\footnotetext{
${ }^{7}$ McIntyre (2005) assumes this decomposition analysis for the causative uses of get as in (i):

(i) John got Mary blamed.
} 
Embick (2003). The subject of the get construction raises to its surface position from inside the participial structure: ${ }^{8}$

$$
\text { John got [RP } \mathrm{t} \text { pushed]. }
$$

Fox and Grodzinsky (1998) provided arguments in favor of such an analysis. These include cases where get can separate idioms chunks, suggesting that the subject must receive its thematic role in its base position:

In the end, advantage always gets taken of John.

The analysis above implies that get is generated in a v/Voice type of head. As such, it has a semi-lexical nature, the result of which is the restrictions on its complement selection. Further research is necessary in order to determine the details of this structure as well as the difference between passive and causative get and its counterparts in the other languages.

\section{References}

Alexiadou, Artemis and Elena Anagnostopoulou. 2005. On the syntax and morphology of Greek participles. Paper presented at the workshop on the Morphosyntax of Modern Greek. LSA Harvard University, July 2005.

Arce-Arenales, M., M. Axelrod and B. Fox. 1994. Active voice and middle diathesis: A cross-linguistic perspective. In Voice: Form and Function, ed. by Barbara Fox and Paul Hopper, 1-22. Amsterdam: John Benjamins.

Cook, Philippa. 2004. The datives that aren't born equal: beneficiaries and the dative phrase. Manuscript, ZAS Berlin.

Corver, Norbert and Henk van Riemsdijk. 2001. (eds) Semi-lexical categories: the function of content words and the content of function words. Berlin/New York: Mouton de Gruyter.

Doron, Edit and Malka Rappaport-Hovav. 1991. Affectedness and externalization. Proceedings of NELS 21: 81-94.

Embick, David. 2003. Locality, listedness and morphological identity. Studia Linguistica 57: 143-169.

Emonds, Joe. 1999. The flat structure expression of semi-lexical heads. Handout for the Conference on Semi-Lexical Heads. Tilburg, May 1999.

\footnotetext{
${ }^{8}$ Others, e.g. Taranto (2004), analyse the get-passive in terms of complex predicate formation where the argument structure of get and the argument structure of the participle 'fall together'. See also Haider (2001). The above proposal crucially differs from such views.
} 
Fanselow, Gisbert. 1987. Konfigurationalität. Tübingen: Narr.

Fox, Dany and Yosef Grodzinsky. 1998. Children's passive: a view from the byphrase. Linguistic Inquiry 29: 312-332.

Givón, T. and L. Yang. 1994. The rise of the English get-passive. In Voice: Form and Function, ed. by Barbara Fox and Paul Hopper, 119-150. Amsterdam: John Benjamins

Haegeman, Liliane. 1985. The get-passive and Burzio's generalization. Lingua 66: 53-77.

Haider, Hubert. 1984. Mona Lisa lächelt stumm: über das sog. deutsche Rezipientenpassiv. Linguistische Berichte 89: 32-42.

Haider, Hubert. 1986. Fehlende Argument: vom Passiv zu kohärenten Infinitiven. Linguistische Berichte 101 3-33.

Haider, Hubert. 2001. Heads and seletion. In Semi-lexical categories: the function of content words and the content of function words, ed. by Norbert Corver and Henk van Riemsdijk, 67-96. Berlin/New York: Mouton de Gruyter.

Harley, Heidi. 2004. Wanting, having and getting. Linguistic Inquiry 35: 355-392.

Huang, C.T. James. 1999. Chinese passives in comparative perspective. Tsing Hua Journal of Chinese Studies.

Kratzer, Angelika. 2001. Building Statives. In Proceedings of the Berkeley Linguistics Society 26.

Labelle, Marie. 2002. The French non-canonical passive. Ms. Université du Quebec á Montréal.

Levin, Beth and Malka Rappaport. 1986. The formation of adjectival passives. Linguistic Inquiry 17: 623-661.

McIntyre, Andrew. 2005. Aspects of the grammar of get. Ms. University of Leipzig.

Reis, Marga. 1985. Mona Lisa kriegt zu viel: vom sog. Rezipientenpassiv im Deutschen. Linguistische Berichte 96: 140-155.

Richards, Norvin. 2001. An idiomatic argument for lexical decomposition. Linguistic Inquiry 32: 183-192.

Riemsdijk, Henk van. 1998. Categorial feature magnetism: the endocentricity and distribution of projections. The Journal of Comparative Germanic Linguistics 2: $1-48$

Siewierska, Anna. 1984. The passive: a comparative linguistic analysis. London: Croom Helm.

Taranto, Gina Christine. 2004. An event structure analysis of causative and passive get. Manuscript. University of California, San Diego. 